\title{
QUESTIONING STRATEGIES IN ENGLISH LITERATURE LECTURES IN AN INDONESIAN UNIVERSITY
}

\author{
Akhyar Rido ${ }^{1}$; Heri Kuswoyo ${ }^{2 *}$; Sandi Nuansa ${ }^{3}$ \\ ${ }^{1,2.3}$ English Department, Faculty of Arts and Education, Universitas Teknokrat Indonesia \\ Jl. Zainal Abidin Pagar Alam No. 9-11, Bandarlampung 35132, Indonesia \\ 1akhyar_rido@teknokrat.ac.id; ${ }^{2 h e r y @ t e k n o k r a t . a c . i d ; ~}{ }^{3}$ sandinuansa41@gmail.com
}

Received: $30^{\text {th }}$ November 2020/Revised: $18^{\text {th }}$ January 2021/Accepted: $21^{\text {st }}$ January 2021

\begin{abstract}
How to Cite: Rido, A., Kuswoyo, H., \& Nuansa, S. (2020). Questioning strategies in English Literature lectures in an Indonesian university. Lingua Cultura, 14(2), 241-253. https://doi.org/10.21512/lc.v14i2.6834
\end{abstract}

\begin{abstract}
The research aimed to investigate the questioning strategies used by lecturers in English literature lectures in Indonesian university and how they were manifested. Applying a qualitative approach and Rido, Ibrahim, and Nambiar's conceptual framework in 2015, the research analyzed three lectures of English literature consisting of prose, literary criticism, and drama. Data were collected through 300 minutes of video-recordings. The findings reveal that the lecturers employ various types of questions such as display, referential, follow-up, and rhetorical questions. The lecturers manifest the questions by rephrasing questions first, then nominating students, asking questions to the entire class, encouraging students to initiate questions, and moving closer to students when asking questions. The questioning strategies help the lecturers to lead the discussion, check students' understanding, offer the students to share ideas, and improve students' participation. As a result, the students become active in expressing thoughts, sharing ideas, and even initiating questions. The research can be a guideline for lecturers to create meaningful and interactive lectures to produce competent and critical students.
\end{abstract}

Keywords: questioning strategies, literature lectures, university

\section{INTRODUCTION}

University students are demanded to have good communication skills, especially in English, to promote their career employment in the future (Afrianto \& Gulö, 2019; Rana, Bashir, \& Abbas, 2020; Rido, 2020a). Not only communication skills but the students must also be equipped with critical thinking skills because those are the top skills to enter the job market in the 21 st century (NACE, 2020; Rido, 2019; Shcheglova, 2019). University students can acquire communication and critical thinking skills from university lectures through interaction (Saleh, 2019; Ranta \& Harmawati, 2017). Interaction is salient for successful university lectures, especially when a twoway communication occurs between the lecturer and students (Almohizea, 2018; Liu, 2019; Sari, 2019).

However, there is still growing concerned in university lectures, especially in English literature lectures in an Indonesian university. Students find that literature lectures are challenging for non-native speakers (NNS) of English. They have to complete tasks given successfully and communicate with each other, besides receiving and sending comprehensible literature content knowledge from and to their lecturers (Rido, 2017). As these students are prepared to be competent English communicators and critical thinkers; therefore, lecturers must be aware of students' language competence and performance as well as enable them to improve their literary knowledge (Rido, Kuswoyo, Ayu, 2020; Shi, 2013).

Mackey (1999) has suggested lecturers systematically plan and manage their questioning strategies not only to make students participate but also to lead them to think critically. Thus, the lecturers must be able to create relevant questions and use them to draw students' attention, lead students to a certain point, exert disciplinary control, get feedback, foster communication, increase participation, and stimulate the students' critical thinking skills (Cahyono \& Pribady, 2020; Johnson \& Picciuolo, 2020; Kiramba \& Smith, 2019; Rido, 2020b; Tan, 2007; Zhang et al., 2018).

Rido, Ibrahim, and Nambiar (2015) have classified questioning strategies that can be employed by lecturers during university lectures 
into two categories: question-planning and questioncontrolling strategies. Question-planning strategies deal with types of questions used by the lecturer, such as open-referential, close-display, rhetorical, and follow-up questions. The main functions are to check the students' understanding of the materials at hand, give students opportunities to respond to questions, invite further discussion, and know the students' interest. Meanwhile, question-controlling strategies are related to the procedure or manifestation in asking the questions. It consists of phrasing questions then calling the student, nominating a specific student to answer questions, asking questions to the entire class, encouraging students to consult with their friends before answering the question, encouraging the students to initiate question, moving closer when asking the question, repeating the question when there is no response, and modify the question when it is difficult to understand. The primary functions are to get the students' attention to ensure that the students can cope with the lectures, to give the opportunity for good students to share with the entire class, to give equal opportunity for students to respond to questions, and to minimize the gap between the lecturer and the students (Meguid \& Collins, 2017; Rido, Ibrahim, \& Nambiar, 2015).

Works of literature have shown that questioning plays an important role in university lectures (Mackey, 1999; Milawati \& Suryati, 2019; Rido, 2019; Yang, 2017; \& Ziyaeemehr, 2016). It is used as a tool to encourage students to actively participate, create an interactive learning atmosphere, and develop communication and critical thinking skills, especially in the university where they must understand, explain, implement, and analyze theories and practices based on their background of expertise. Besides, studies also show that students who actively participate in lectures demonstrate clearer and higher linguistic as well as knowledge improvements (DeWaelsche, 2015; Fard, 2016; Kiramba \& Smith, 2019; Liu, 2019; Mahmud, 2017; Rido, 2017, 2019; Shi, 2013; Wangru, 2016).

Several studies have been conducted in the university context discussing questioning strategies (Rido, 2019; Shi, 2013; Tan, 2007; Wangru, 2016). Rido (2019) recently has investigated the use of questions in science lectures in Malaysia and reveals that the lecturer employs many display and referential questions to guide the students to understand the material and stimulate their critical thinking. He has suggested that lecturers should use various types of questions and ways to promote learning. Shi (2013) has researched literature classrooms in Hong Kong tertiary institutions. He has found the diversity of open-ended questions posed by the lecturers, which require a lengthy response, not simply by right or wrong. Most of the questions demand the students show their standpoint with specific and detailed statements. Other questions are posed to check the students' understanding of literary technical terms. The research also indicates that the students experience linguistic improvements, mainly enlargement of vocabulary and enhancement of the command of literary technical terms. Meanwhile, Tan (2007) has looked at how questioning strategies are used in a Chinese university lecture. The research has found that traditional culture and the lecturer's inability to employ questioning strategies negatively impact the students. It suggests that the lecturer must be willing to accept any answers from the students, even it is a strange answer, so the students will not feel embarrassed to respond. Wangru (2016) has examined questioning strategies used in the Henan Polytechnic University lecture. He has revealed that questioning strategies have positive impacts on students' learning. However, sometimes the lecturer does not employ the questioning strategies in an ideal way. The class activity is dominated by display questions and becomes less interactive. He has suggested that the lecturer should increase the number of referential question to have more interactive learning.

However, research on questioning strategies in an Indonesian university literature lecture context are still limited. Therefore, it is important to investigate how the lecturer's questioning strategies in literature lectures fill the gap in knowledge of the existing topic and be a guideline for lecturers to improve their pedagogical practices. Thus, the research aims at revealing questioning strategies used in literature lectures, focusing on the types of questions and how they are manifested.

\section{METHODS}

The research applies a qualitative approach. It investigates a phenomenon in a natural setting, questioning strategies used in literature lectures, and how they are manifested (Creswell \& Creswell, 2018; Leavy, 2017). The participants of the research, Mr. Daniel (lecturing prose - LE 1), Mr. Smith (lecturing literary criticism - LE 2), and Miss Dolly (lecturing drama - LE 3) - pseudonyms, are purposively selected based on a set of criteria such as at least having a masters degree in literature and more than five-year experience in teaching literature courses in English. Besides, they must be recommended by the head of the department and their colleagues as well as willing to be the participants of the research. Information given to all participants includes what the research is all about, what would be done during the research, how results would be reported, what the participants gained from the study, and what this research would contribute to relevant stakeholders.

Once the participants agree to participate in the research, the data are collected by video recording their lectures. Video Recording is the best instrument to know the complete interaction between the lecturer and the students during the lectures. It enables the researchers to have more detailed information because every word is recorded. It provides more contextual data, including the participants' facial expressions and body movements (Blikstad-balas, 2017; Ranta \& Harmawati, 2017). Video recording also gives a 
permanence, which allows the researchers to replay the event (Reid et al., 2015; Merriam \& Tisdell, 2016; Rido, 2019; Rido et al., 2015) so the researchers can have more time to contemplate, consider, and ponder the data before drawing conclusions in order to avoid premature interpretation of the data.

The video recording process is conducted in prose, literary criticism, and drama lectures attended by $40-50$ students. A video camera on a tripod is placed in the back corner of the classroom to capture the dominant view during the lecture. Each video recording lasts 100 minutes. In total, there are three videos successfully recorded with 300 minutes duration. The videos are then transcribed orthographically using transcription conventions by Jefferson (2004), Hauser (2006), and Simpson, Lee, and Leicher (2002), which are revised to suit the objective of this research in a Ms. Word program in the form of a table. Line numbering indicating turn-taking is given on the left of the page to ease reference and facilitate analysis. Peer debriefing is used to ensure the validity of the gathered data. A linguistic expert helps the researchers in examining the accuracy of the results of transcriptions. Member checking is also carried out as an identification process to get confirmation from the participants. After the transcriptions are neatly written, all participants verify if the transcriptions have been correctly noted. This is done to establish the credibility of the data obtained.

After that, the data are analyzed using five steps. The first step is building a database. All data gathered from video recordings are organized and labeled in separate files in one folder or database. Second, opencoding is done. Here, the data are studied carefully, and the researchers open to any possible categories. Third, after open-coding the data, similar questioning strategies might be developed, and the emergent themes are obtained. Fourth, after having the emerging themes, focused-coding is conducted to classify them into sub-categories. Fifth, the final emerging themes are presented.

\section{RESULTS AND DISCUSSIONS}

The research aims at investigating the use of questioning strategies in English literature lectures in an Indonesian university. The results indicate that all lectures are dominated by a huge exchange of question and answer activity. All lectures use various types of questions and are manifested in many ways. Based on data analysis, four uses of question-planning strategies are found: close-display question, open referential questions, follow-up questions, and rhetorical questions.

First, all lecturers employ display questions using modal 'can', auxiliary 'do' and 'have', and the linking verb 'is' and 'are'. In the following extract, Mr. Smith utilizes display question 'can' in his lecture.

Extract 1: LE (2)
327 L ok, so your argument will be ok,

328 because you learn and you study

329 that scholarly, ok thank you,

330 anyone ask questions? (.) to share

$331 \quad$ idea? (.) No (/) Can we proceed?

332 Ss Yes

In extract 1, Mr. Smith summarizes and thanks to his students for their response (lines 327-329). After that, in line 330 , he offers the student an opportunity to ask the question and share more ideas. Because there is no response from the students, in line 331, he confirms the floor using display question 'can' so they could move to the next discussion. In line 332, the floor gave a choral response, 'yes', indicating an agreement.

In her drama lecture, Miss Dolly also uses display question with 'can'.

Extract 2: LE (3)

164

L Can we become the character in

165 the book?

166

Ss Yes (.) can (.) could be

In extract 2, Miss Dolly is discussing characters with the students. She poses a display question using modal 'can' to know the students' understanding of the materials at hand, characters in reality, and the book (lines 164-165). In line 166, the entire class said 'yes (.) can (.) could be', indicating a possibility that real characters like them could be characters in the book.

Furthermore, display questions combining auxiliary 'do' and the linking verb 'is' are also found. It can be seen in extract 3 .

\begin{tabular}{|c|c|}
\hline 796 & Mm, Uning said that he is fast \\
\hline 797 & thinker (.) fast thinking or fast \\
\hline 708 & thinker. And after that, he is also \\
\hline 99 & smart and liar. Another one for \\
\hline & the boy (.) Do you want to add \\
\hline & some more? Speech, ok, from \\
\hline & action and thought. Is that all? Is \\
\hline & that all? Yustian, you want to add \\
\hline & something? No (/) Now, we move \\
\hline & to the lady. \\
\hline
\end{tabular}

In extract 3, Mr. Daniel is discussing the characteristic of a character in a story. In lines 796799 , he just resumes a student's idea (Uning). In lines $800-802$, he asks another display questions using 'do' and the linking verb 'is' to confirm the student's final answer and offer another chance to speak more. After learning that no one is going to talk, he decides to move to the next discussion (lines 804 805).

Extract 4 reveals that Mr. Smith poses a yes/no question using the auxiliary 'do'. 


$\begin{array}{lll}245 & \text { L } & \text { how to put yourself in certain } \\ 246 & & \text { context nobody can make it, ok, } \\ 247 & & \text { but through literary work, you } \\ 248 & & \text { understand, why this person is } \\ 249 & & \text { suffering, ok because he is the } \\ 250 & & \text { one typically behaving in this } \\ 251 & & \text { way within the society. Do you } \\ 252 & & \text { get what I mean? } \\ 253 & \text { Ss } & \text { Yes }\end{array}$

Mr. Smith is explaining the context of literary work to the students (lines 245-250). After that, in lines 251-252, he asks a display question using 'do', which is posed in order to check the student's understanding towards the point of explanation. The students then answer in chorus, stating that they understand the explanation (line 253).

Meanwhile, Miss Dolly poses question with 'do' as confirmation check.

Extract 5: LE (3)

$$
\mathrm{L}
$$

Do you still remember him? ((point the screen))

\section{Ss Oh yeah William Shakespeare}

In extract 5, Miss Dolly displays a picture on the screen and asks display questions to the entire class using 'do' to check and recall the students' memory about the literature figure (line 61). In line 63 , the students confirm that the picture is William Shakespeare.

Meanwhile, in extract 6, Mr. Smith employs display questions using linking verb 'is' and 'are'.

Extract 6: LE (2)

$\begin{array}{lll}224 & \text { L } \quad & \text { all experiences, as long as human } \\ 225 & & \text { sense something, see something, } \\ 226 & & \text { listen something, so we can get } \\ 227 & & \text { the experiences of what is being } \\ 228 & & \text { listened, what is ee watched, } \\ 229 & & \text { what is heard, ok? Is that } \\ 230 & & \text { answering? } \\ 231 & \text { S } & \text { Ok }\end{array}$

Mr. Smith tries to answer a female student's question (lines 224-228). In the end part, he confirms the student whether he answers her question (lines 229-230). In line 231, the student confirmed by saying 'ok', indicating that she gets the point.

Here, in extract 7, Miss Dolly utilizes display questions with linking verb 'are'.
156
157
L In your life (.) are we character?
Ss Yeah yeah

In the lecture, Miss Dolly discusses character and characterization with the students. Then, she starts asking a display question, 'are we characters?' (line 156) which is actually done in order to stimulate discussion. In line 157, all students respond with 'yeah', showing their agreement.

Next, the research has found display questions using auxiliary 'have' during Mr. Smith's lecture (extract 8).

\section{Extract 8: LE (2)}

\begin{tabular}{|c|c|c|}
\hline 689 & $\mathrm{~L}$ & So, this is the things we advice \\
\hline 690 & & you to find the current one, and \\
\hline 691 & & today we have many accesses, \\
\hline 692 & & right? You can find the pdf \\
\hline 693 & & version for free, ok, if you want \\
\hline 694 & & to go to perpusnas, perpustakaan \\
\hline 695 & & nasional $<$ national library $>$, \\
\hline 696 & & have you registered yourself? \\
\hline & Ss & Not yet \\
\hline
\end{tabular}

In the middle of his lecture, Mr. Smith suggests his students access free reading materials from the national library (lines 689-695). After that, in line 695 , using display question with auxiliary 'have', he confirms whether the students have already registered themselves or not. The students give their choir response 'not yet', indicating that they have not registered as a member (line 697).

In the same vein, Miss Dolly uses display questions with 'have' in her lecture. It can be seen in extract 9 .

Extract 9: LE (3)

$$
\begin{array}{lll}
72 & \text { L } & \text { Ok. Have you read Hamlet? } \\
73 & \text { Ss } & \text { No }
\end{array}
$$

At the beginning of the lecture, Miss Dolly checks the students' reading. In line 72 , she asks a display question using auxiliary 'have' to know whether the students have already read Hamlet or not. In line 73, the students state that they have not read Hamlet. Here, she wants to measure the students' knowledge before explaining the materials.

Second, all lecturers employ referential questions in various forms. The questions are employed using WH-question such as 'what', 'how', 'where', and 'why'. Extract 10 reveals that Mr. Daniel utilizes referential questions using 'what' in his lecture. 
573

L There are five different methods

574

575

576

577

578

579

580

581

582

583

584

585

586

587 of direct characterization. Five methods, five, five., five, five. Number one is, you remember about STEAL? Ok, STEALspeech, thoughts, effect on others towards the characters, action, and looks. Speech, what is the meaning, Keanu?

S Mm it's about the way we talk

L Yeah, the way the- ee we talk to others. Ok, Putri, what about thought?

S The way we think about something.

In the lecture, Mr. Daniel reviews the five methods in analyzing characterization, STEAL (lines 573-579). Using referential question 'what', he checks some students' understanding towards the materials at hand, the concept of STEAL. First, he nominates a male student named Keanu to explain speech (lines 580-581). After that, he selects a female student named Putri to respond to question about thought (lines 584585). The students give their response in lines 582 and 586-587.

In the same vein, Miss Dolly also uses referential questions with 'what' in her lecture. It can be seen in extract 11.

Extract 11: LE (3)
$\begin{array}{lll}245 & \text { L } & \text { What do you know about him } \\ 246 & & \text { when you watch the movie (.) } \\ 247 & & \text { what do you get from the } \\ 248 & & \text { conversation? } \\ 249 & \text { S } & \text { Oo, He is an anger man (.) And } \\ 250 & & \text { he (...) even when he angry. He } \\ 251 & & \text { always he always says to his } \\ 252 & & \text { enemy (.) what is that? aaa to his } \\ 253 & & \text { enemy he says to him as a dog (.) } \\ 254 & & \text { that dog (.) kill them all. }\end{array}$

In extract 11, Miss Dolly discusses character and characterization in a movie. In lines 245-248, she asks a student about the characterization of a character in the movie, particularly from the conversation. The student gives his response about the characterization (lines 249-250), followed by evidence from the conversation (lines 251-254). It indicates that he could follow the lecture. employ referential questions using 'how'. In extract 12, Mr. Daniel uses the question in his lecture.

Extract 12: LE (1)

$\begin{array}{lll}563 & \text { L } & \text { Directly write down- the author. } \\ 564 & & \text { Next, indirect characterization, ok. } \\ 565 & & \text { Do you believe me when I say } \\ 566 & & \text { 'Hey, I am very dilligent.' Do you } \\ 567 & & \text { believe me? } \\ 568 & \text { S } & \text { Not really. } \\ 569 & \text { L } & \text { Not really. How can you believe } \\ 570 & & \text { me? } \\ 571 & \text { S } & \text { I have to see the proof, the action. }\end{array}$

In extract 12, Mr. Daniel discusses indirect characterization with the students (lines 563-564). In lines 565-567, he checks the students' understanding of the materials at hand by posing whether they believe if he says he is a diligent person. In line 568, the students answer that they do not believe the statement. In lines 569-570, he then asks a referential question to the entire class to make them believe him. In line 570 , a student responds by saying that he needs to see his action as evidence that he is a diligent person, indicating that the student understands the concept of indirect characterization.

In the same vein, Miss Dolly uses referential questions combining 'where' and 'how'.

\section{Extract 13: LE (3)}

286 L Ok. where can you get the idea that

287 he is smart? Brave? (.) How you can

288 tell me the conversation from the

289 movie guys?

290 S Aaa he is brave (0.2) he is brave

291 because he fights the snow witch

292 L The snow witch

293 S Yes the snow witch (.) And then

294 a (...) (0.3) he always he helps the

$295 \quad(0.4)$ the resident of Narnia.

In extract 13, Miss Dolly discusses character and characterization in her drama class. In lines 288289 , using questions with 'where' and 'how', she wants the students to explain with evidence that the character that they are discussing is smart and brave by looking at the conversation in the movie. In lines 290-291, a student explains that the character is brave because he fights the snow witch and helps the people of Narnia, showing that he is able to explain and give the evidence.

Furthermore, the referential question with why was also used by Mr. Daniel in extract 14 . 


\begin{tabular}{|c|c|c|}
\hline 973 & $\mathrm{~L}$ & $\begin{array}{l}\text { Have no fear. Ok. Why? Why he } \\
\text { has no fear? }\end{array}$ \\
\hline 974 & & has no fear? \\
\hline 975 & & Because he just like relax to what \\
\hline 976 & $\mathrm{~S}$ & happen (.) enjoy about what \\
\hline 977 & & happen to him even dangerous \\
\hline 978 & & him \\
\hline 979 & $\mathrm{~L}$ & Ya, just do it. Ok. Thank you (.) \\
\hline 980 & & argument is always found you \\
\hline 981 & & know if ee as far as you can sho \\
\hline 50 & & the proof... \\
\hline
\end{tabular}

In extract 14, Mr. Daniel discusses character and characterization in his lecture. They identify that there is a character with no fear (line 973). Next, he demands evidence from the students why the character has no fear (lines 973-974). A student then responds by explaining that the character always stays calm even though he is in danger (lines 975-978). In lines 979982, the lecturer thanks the student and tells him that he could accept the argument and evidence.

Similarly, Mr. Smith also posed the 'why' question, and it can be seen in extract 15 .

Extract 15: LE (2)

\begin{tabular}{|c|c|c|}
\hline 90 & $\mathrm{~L}$ & Why literature does matter? (.) \\
\hline 91 & & last time some of you responded \\
\hline 92 & & literature does matter because a, \\
\hline 93 & & b, c. I want you to refresh what \\
\hline 94 & & we have discussed last time, \\
\hline 95 & & anybody can share, ok what about \\
\hline 9 & & you ((point a female student))? \\
\hline
\end{tabular}

In extract $15, \mathrm{Mr}$. Smith revisits the previous material in his literary criticism class; therefore, he poses the question 'why literature does matter?' which is a topic from the previous lecture (lines 90-94). Here, he wants the students to share their ideas and use their reasoning skills (line 95). In the end, a female student is nominated to share her ideas (line 96).

In extract 16, Miss Dolly utilizes referential questions using 'why' as well.

\section{Extract 16: LE (3)}

L Why Katniss Everdeen in the hunger games try to kill the president snow?

S Because she wants aaa to save her sister (.)Her sister her sister being secretive for to be a volunteer
In extract 16, Miss Dolly discusses Hunger Games movie in her drama class. She poses a question as she wants to hear the students' response to why Katniss Everdeen attempted to kill President Snow (lines 773-775). In lines 776-778, a student volunteers to give her response, explaining that Katniss's motive is to save her sister.

Third, all lecturers employ follow up question. The follow-up questions used are the combination of display and referential questions using WH-question such as 'what', 'how', modal 'can', auxiliary 'have' and 'do', and raising intonation. Extract 17 shows how to follow up questions are used by Mr. Daniel.

Extract 17: LE (1)

$\begin{array}{lll}822 & \text { L } & \text { What she gives? She gives (/) } \\ 823 & \text { S } & \text { She gives the ball back to the boy. } \\ 824 & & \text { So, I think she is kind. } \\ 825 & \text { L } & \text { She is kind. Ok. } \\ 826 & \text { S } & \text { Kind and bad temper } \\ 827 & \text { L } & \text { Kind and good tem- temper. } \\ 828 & \text { S } & \text { Bad temper based on the speech. } \\ 829 & & \text { ball to the girl. So, bad temper } \\ 830 & & \text { and kind. } \\ 831 & \text { L } & \text { And (/) } \\ 832 & \text { S } & \text { And by the thought, she is stupid. } \\ 833 & \text { L } & \text { By thought, she is stupid. Why? } \\ 834 & \text { S } & \text { Because she is easy to fool. } \\ 835 & \text { L } & \text { Ok }\end{array}$

Mr. Daniel's lecture in extract 17 is dominated by a long chunk of question-answer activity. First, in line 822 , he poses a 'what' question to the students. In line 823 , a female student initiates to give a response. She adds more answers in lines 826 and 828-830. Unsatisfied with the response, a follow-up question using 'and (/)' is indicated by the rising intonation posed in line 831. Again, the student gives her response in line 323. Further, he asks another follow up open referential question with 'why'. He wants the student to give evidence to strengthen her previous answer and invite for more discussion. In line 834, the student gives her response, which is accepted by the lecturer (line 835).

The use of more follow up question can be seen from Mr. Smith's lecture in extract 18.

Extract 18: LE (2)

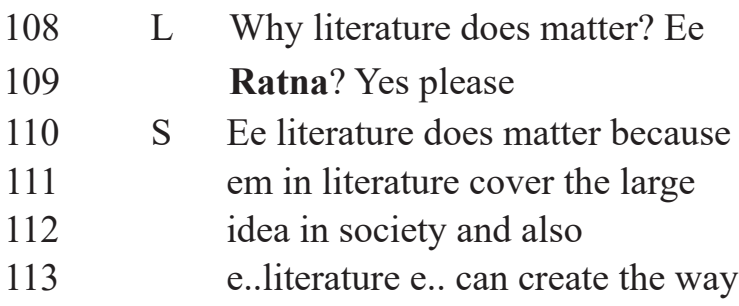


In extract 18, Mr. Smith explains the previous topic, 'why does literature matter?' In lines 108-109, he poses the same question and offers a chance for a student to share her ideas. In lines 110-116, she gives a lengthy response that literature could be a learning source for others and a platform for sharing experience. In lines 117-125, Mr. Smith agrees with the student's response and emphasizes the importance of learning from somebody else's experience; how to contextualize it in a personal situation. This is followed by another follow-up question with a rising intonation (line 126), indicating that he allows her to speak more. In lines 127-133, the student elaborates more by telling everyone that literature could build empathy and critical thinking skills.

Extract 19 also indicates that Miss Dolly asks a follow-up question to her student.

Extract 19: LE (3)

$\begin{array}{lcl}275 & \text { L } & \begin{array}{l}\text { The Chronicle of Narnia (.) Have } \\ \text { you read book from The chronicle }\end{array} \\ 276 & & \begin{array}{l}\text { of Narnia? } \\ 277\end{array} \\ 278 & \text { Ss } & \text { Yes. } \\ 279 & \text { L } & \text { How many book series of Narnia? } \\ 280 & \text { S } & \text { Five } \\ 281 & \text { L } & \text { Seven } \\ 282 & \text { S } & \text { Oh seven ya. } \\ 283 & \text { L } & \text { Seven books (.) Ok, guys listen (.) } \\ 284 & & \text { Ok. What are the characters? } \\ 285 & \text { S } & \text { Aaa King Peter. }\end{array}$

According to extract 19, Miss Dolly wants to discuss The Chronicle of Narnia with the students. First, using a display question 'have', she checks whether the students have read the book or not (lines 275-277). In line 278, the students give a choir response 'yes', showing that they have read it. After getting such a response, the lecturer poses a follow-up question to check the students' knowledge about the total series of Narnia (line 279). In line 280, a male student gives a response by saying 'five', but directly corrected by the lecturer by mentioning 'seven', indicating that the correct answer is seven series (line 281). The student repairs his answer by saying 'oh seven ya', indicating he realizes his mistake and agrees with the lecturer's correction. After giving his confirmation of the student response (line 283), Miss Dolly continues asking follow-up questions using 'what' to know the characters in Narnia Story (line 284). In line 285, the student mentions one name, King Peter, as one of the characters.

Fourth, all lecturers employ rhetorical questions. The questions are employed using WH-question such as 'what', 'why', 'how', and raising intonations. In extract 20, Mr. Daniel uses rhetorical questions during his lecture.

Extract 20: LE (1)

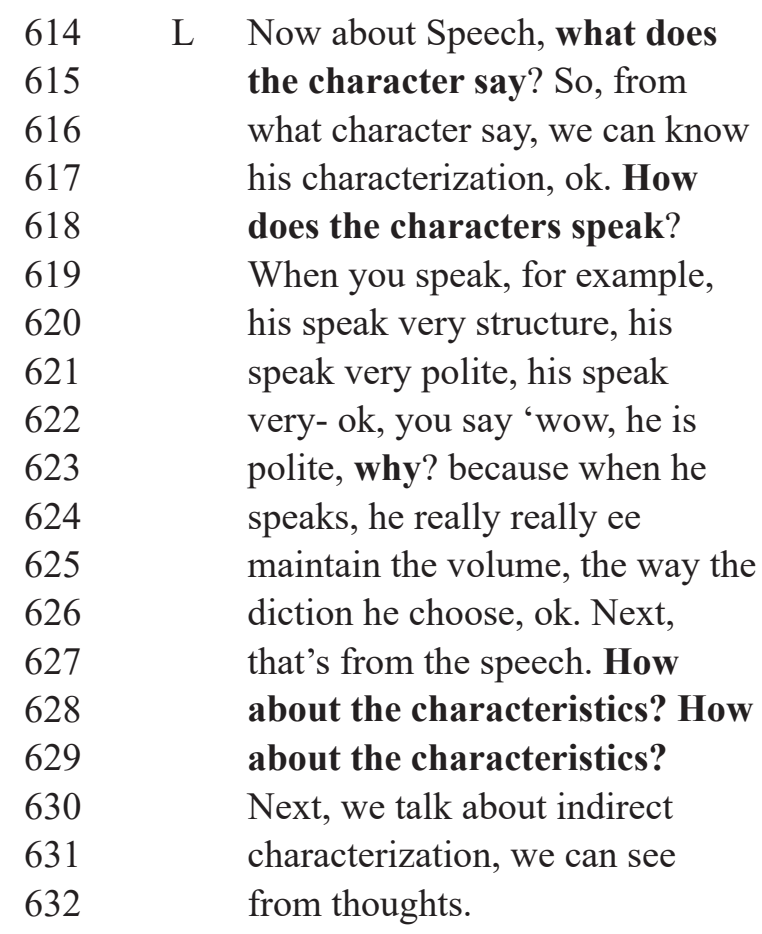

In extract 20, Mr. Daniel explains character and characterization to the students. In lines 614-615, he asks a rhetorical question, 'what does the character say?', then explains by himself that characterization could be identified from what the character said. In lines 617-618, he uses another rhetorical question, 'how does the character speak?', and again, continues explaining that it could be seen from the structure of the sentence as well as the use of politeness strategy. In line 622, he continues and this time employs a rhetorical question with 'why' to explain the evidence of a polite character that could be seen from his speech volume and word choice. More question is posed 'how 
about the characteristics?' (lines 627-629), followed by a discourse marker 'next', signaling a transition that they would move to the next discussion, analyzing characterization from thoughts (lines 630-631).

Similarly, Mr. Smith also employed rhetorical questions that can be found in extract 21 .

Extract 21: LE (2)

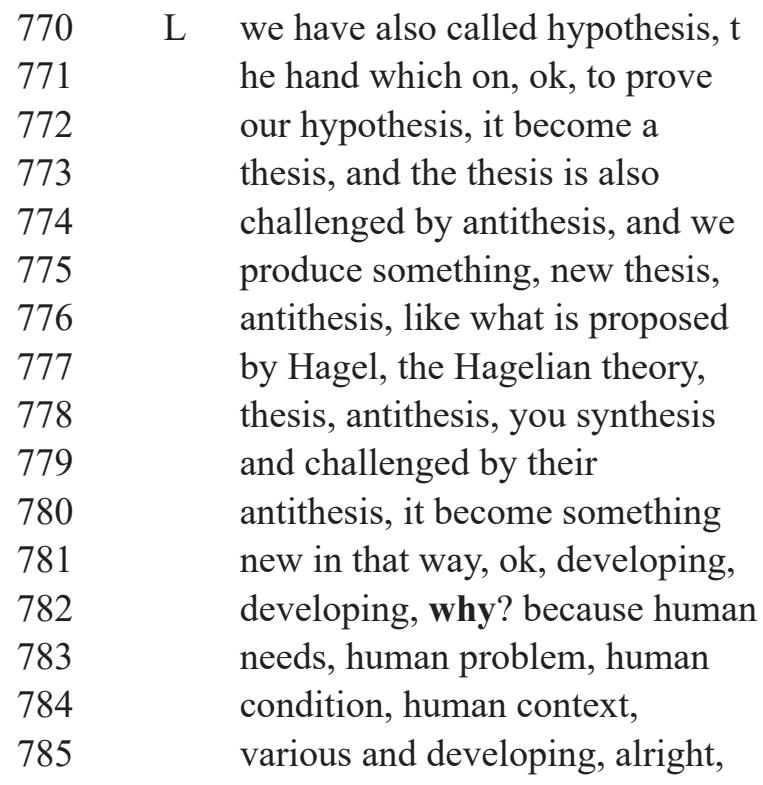

In extract 21, Mr. Smith explains the hypothesis and how it is challenged, then he quotes Hegelian Theory (lines 770-780). In the middle of his explanation, he uses a question with 'why' (line 782). $\mathrm{He}$ answers his own question that hypothesis is always developing because of several factors such as human needs, condition, and context (lines 783-785).

While in extract 22, Miss Dolly also uses rhetorical questions.

Extract 22: LE (3)

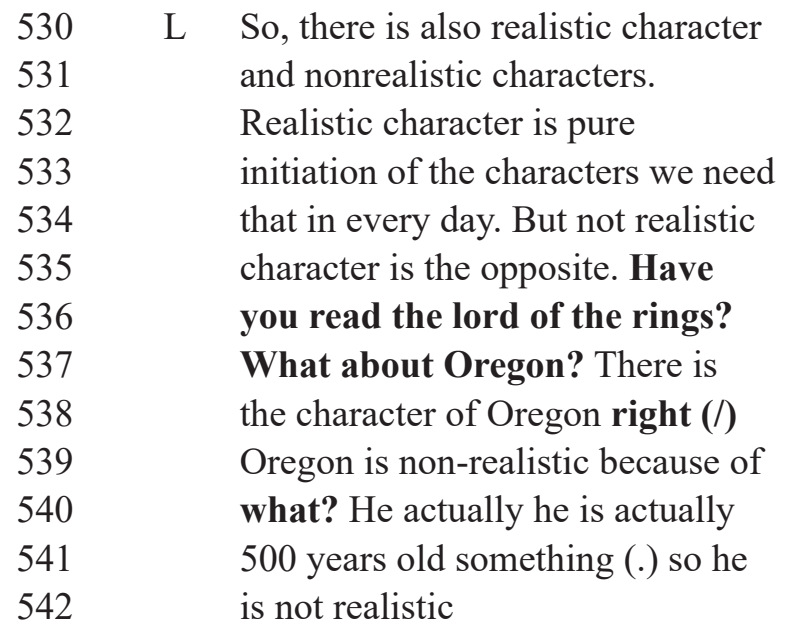

During the lecture, Miss Dolly explains realistic and non-realistic characters (lines 530-535). After that, he poses four consecutive rhetorical questions to the students. First is confirming whether they have read Lord of the Rings or not (lines 535-537), second is asking a character named Oregon (line 537), third is emphasizing the existence of Oregon character (line 358 ), and fourth is asking the reasons why Oregon is not a realistic character (lines 539-540). Finally, in lines 541-542, he explains that Oregon is not a realistic character as he is actually 500 years old.

The findings also reveal that all lecturers use various ways in manifesting the questions, such as through (1) rephrasing question first then nominate students, (2) asking questions to the entire class, (3) encouraging student to initiate question, and (4) moving closer to the student when asking the question.

First, all lecturers rephrase the question then nominate a student to give the response. Extract 23 shows how Mr. Daniel manifests this strategy.

Extract 23: LE (1)

$\begin{array}{lll}330 & \text { L } & \begin{array}{l}\text { Next, based on character's } \\ \text { characterization, flat and round. }\end{array} \\ 331 & & \text { what is flat, Yasrin? (.) and what } \\ 332 & & \text { is round, Billy? (0.5) Yasrin (/) } \\ 333 & & \text { flat (/) } \\ 334 & & \text { S } \\ 335 & \text { Flat character, character who has } & \text { one single character. }\end{array}$

Mr. Daniel discusses flat and round character with the students (lines 330-331). To check the student's understanding, he first phrases the questions and then nominates two students named Yasrin and Billy to respond to the questions (lines 332-334). In lines 335-336, Yasrin gives his response that flat character only has one single character.

In extract 24, Mr. Smith also uses the same strategy, rephrasing the question then nominating the student.

Extract 24: LE (2)

$\begin{array}{lll}559 & \text { L } & \text { We'll make it deeper yaa, thank } \\ 560 & & \text { you, any more response before we } \\ 561 & & \text { go to the next, yes, can we use } \\ 562 & & \text { more than one theory to analyze } \\ 563 & & \text { a story, Beaty? } \\ 565 & \text { S } & \text { Yes sir }\end{array}$

Mr. Smith discusses the use of theory for literary criticism and just thanked a student who gives a response (lines 559-559). After that, in lines 560-563, he rephrases a question then selects a female student to respond to the question about using more than one theory to analyze a literary work. In line 565 , she gives her short response, 'yes sir', indicating his agreement.

Meanwhile, in extract 25, Miss Dolly also uses the same strategy in her lecture. 


$\begin{array}{lll}292 & \text { L } & \text {...you can see the movie and also } \\ 293 & & \text { from the literature about } \\ 294 & & \text { characters. Who else? What } \\ 295 & & \text { would you like to say about } \\ 296 & \text { character, Keanu? ((raise right } \\ 297 & \text { hand)) }\end{array}$

Miss Dolly discusses character and characterization with movies and novels the students (lines 292-294). Next, in lines 294-296, she poses a question and invites a student named Keanu to share his idea about the character.

Second, all lecturers ask the question to the entire class. Extract 26 shows that Mr. Daniel employs the strategy in his lecture.

Extract 26: LE (1)

$\begin{array}{lll}276 & \text { L } \quad \begin{array}{l}\text { What about based on } \\ \text { character's function- based on } \\ \text { the character's function. }\end{array} \\ 277 & & \begin{array}{l}\text { Function of the character } \\ \text { inside of the story, there are }\end{array} \\ 579 & & \begin{array}{l}\text { two, ok? } \\ 280\end{array} \\ 281 & \text { Ss } & \text { Antagonist and protagonist. }\end{array}$

Mr. Daniel explains character and characterization, and he asks the class about characters based on function (lines 276-280). In line 281, the students give their answer in chorus 'antagonist and protagonist', which indicates that they understand the materials at hand.

In different lecture, Mr. Smith employs similar strategy, asking question to the entire class.

Extract 27: LE (2)
$\begin{array}{lll}680 & \text { L } & \text { I mean the theory is developed } \\ 681 & & \text { based on the context based on } \\ 682 & & \text { certain instrument that developed } \\ 683 & & \text { at that time (.) so when you refer } \\ 684 & & \text { to this reference, not valid } \\ 685 & & \text { anymore because the situation is } \\ 686 & & \text { different, do you understand? } \\ 687 & \text { Ss } & \text { Yes }\end{array}$

In extract 27, Mr. Smith explains the theory development based on the context or the current situation (lines 680-685). In line 686, he asks a display question, 'do you understand?' to the entire class to check their understanding of the explanation. In line 687 , the students confirm that they understand the point by saying 'yes'.

Like Mr. Daniel and Mr. Smith, Miss Dolly frequently poses questions to the entire class, which can be seen in extract 28 .

\begin{tabular}{|c|c|c|}
\hline 428 & $\mathrm{~L}$ & Ok. So that's minor character. \\
\hline 429 & & They are less important than \\
\hline 430 & & major characters but they are stil \\
\hline 431 & & important. Because they still \\
\hline 432 & & influence the development of the \\
\hline 433 & & plot. Can you give me example \\
\hline 434 & & of minor character?(.) ((raise \\
\hline 435 & & right hand)) Ok in a movie (.) \\
\hline 436 & & hhm like ok.. Hunger Game \\
\hline 43 & & movie who is the minor \\
\hline 438 & & character in the movie? \\
\hline 440 & Ss & Peeta \\
\hline 44 & $\mathrm{~L}$ & Peeta Mellark (/) minor or \\
\hline 442 & & major (/) \\
\hline 44 & Ss & Major \\
\hline
\end{tabular}

In her lecture, Miss Dolly explains the importance of minor characters for plot development (lines 418-433). In lines 433-438, she asks the students to give an example of a Hunger Game movie's minor character. In line 440, the entire class mentions the minor character named Peeta. Then, in lines 441442 , she confirms the students' answer by raising her intonation, indicating a confirming question. In line 443 , the students correct their answer that Peeta is a major character in the movie.

Third, all lecturers always offer and encourage their students to initiate questions. In extract 29, Mr. Daniel encourages his students to ask the question.

Extract 29: LE (1)

$\begin{array}{lll}367 & \text { L } & \begin{array}{l}\text { But later, you got to change your } \\ \text { mind- I have to be brave, brave }\end{array} \\ 368 & & \text { and brave then you become a } \\ 369 & & \text { brave, brave girl, brave boy, so } \\ 370 & & \text { you can change, your experience } \\ 371 & & \text { changing, ok, that is in reality, } \\ 372 & & \text { but actually our focus is in } \\ 373 & & \text { literary works (.) Question } \\ 374 & & \text { please (/) } \\ 375 & \text { S } & \begin{array}{l}\text { Sir (/) ((raise hand) What is the } \\ \text { difference between static and }\end{array} \\ 376 & & \text { flat character? }\end{array}$

In the middle of his lecture, Mr. Daniel gives an example of character development in real life and literary work by showing self-motivation to be brave so the students' minds and experience could be transformed (lines 367-373). In line 375, he offers the students to ask a question by raising his intonation. This is directly responded by a student who raises his hand and asks about the difference between static and flat characters (lines 376-378). 
In extract $30, \mathrm{Mr}$. Smith motivates his students to ask the question as well.

Extract 30: LE (2)

207

208

209

210

211

212

213

214

215

216

217

218

219

220

221
L Yeah, to develop our critical thinking, you see and you can decide, even though you understand, ok you recognize, ok, the characters, the setting, ok, when it is design in this way the plot will be.. Ok.. When you do, when you make critical analysis, yes (.) question (/) Hari (/)

S I have a question, why we, e, they, they are talking about the literature is like we can experience from the literature, so ee what kind of experience of our life we can put into literature?

At the beginning of his lecture, Mr. Smith explains and emphasizes critical thinking skills in literary criticism by analyzing characters, setting, and plot (lines 207-214). At the end of his explanation, he encourages a male student to ask a question (line 215). After getting the opportunity, the student asks what kind of life experience could be part of literary work (lines 216-221).

Miss Dolly also encourages her students to ask a question that can be seen in extract 31 .

\section{Extract 31: LE (3)}

\begin{tabular}{|c|c|c|}
\hline 441 & $\mathrm{~L}$ & He is less important than major \\
\hline 442 & & characters like Katniss and Vita, \\
\hline 443 & & but he still gives contribution to \\
\hline & & the plot of story. Ok. so that's for \\
\hline & & minor character (.) yes, \\
\hline & & questions (/) \\
\hline 47 & $\mathrm{~S}$ & Miss? (raise hand)) \\
\hline 148 & $\mathrm{~L}$ & Yes. \\
\hline 49 & $\mathrm{~S}$ & Can we call the antagonist \\
\hline & & major minor? because they also \\
\hline & & involve and give contribution in \\
\hline & & story. \\
\hline
\end{tabular}

In extract 31, Miss Dolly explains the contribution of a minor character to a story's plot (lines 441-445). At the end of her explanation, she encourages her students to ask the question (line 446). In line 447 , one raises his hand, indicating that he wants to ask the question. In line 448 , the lecturer allows him to pose his question. After that, the student asks the possibility for an antagonist character to be a major-minor character.

Fourth, all lecturers move closer when they are asking questions. Extract 32 shows how this strategy is manifested by Mr. Daniel.

Extract 32: LE (1)

\begin{tabular}{|c|c|c|}
\hline 153 & $\mathrm{~L}$ & Now, we talk about physical \\
\hline 154 & & appearance. What do you think \\
\hline 155 & & about his physical appearance? \\
\hline 156 & & ((approach a student)) \\
\hline 157 & $\mathrm{~S}$ & Ee has light skin. \\
\hline 158 & $\mathrm{~L}$ & What? \\
\hline 159 & $\mathrm{~S}$ & Light skin. \\
\hline 160 & $\mathrm{~L}$ & Light skin. Next (/) ((move to \\
\hline 16 & & another student)) \\
\hline 162 & $\mathrm{~S}$ & Handsome \\
\hline
\end{tabular}

Mr. Daniel's lecture is dominated by an exchange of question and answer activity. While discussing a character's physical appearance (lines 153-154), he asks a question and approaches a female student (lines 155-156), indicating that he wants the student to respond to his question. After getting an answer from the student (lines 157 and 159), he then poses a similar question and moves closer to another female student (lines 160-161). This female student is aware of the situation and directly gives her response (line 162).

Along the same vein, Mr. Smith also moves closer to his students while asking questions.

Extract 33: LE (2)

$\begin{array}{lll}352 & \text { L } & \begin{array}{l}\text {.. what do you know about } \\ \text { approach, theory? any more }\end{array} \\ 353 & & \begin{array}{l}\text { ideas to share? yes (/) } \\ 354\end{array} \\ 355 & & \begin{array}{l}\text { ((approach and point one } \\ \text { student)) }\end{array} \\ 356 & & \text { Based on that I know from some } \\ 357 & \text { S } & \begin{array}{l}\text { articles theory is a set of } \\ 358\end{array} \\ 359 & & \begin{array}{l}\text { statement e.. to explain a group } \\ \text { of phenomena in literary work, }\end{array} \\ 360 & & \text { and approach is a perspective or } \\ 361 & \text { believe e.. to interpret the literary } \\ 362 & \text { work. }\end{array}$

Mr. Smith discusses theory and approach in his literary criticism lecture, and he wants to check the students' understanding. In lines 352-356, while asking the concept of approach and theory, he moves closer and points a male student, showing that he wants him to talk. In line 356-363, the student explains what he knows about theory and approach. 
In extract 34 , a similar strategy is manifested by Miss Dolly in her lecture as well.

Extract 34: LE (3)

\begin{tabular}{|c|c|c|}
\hline 52 & $\mathrm{~L}$ & ... yes sir $(/)$ what is character? \\
\hline 53 & & (.) do you want to say something \\
\hline 54 & & (/) ((approach one student)) \\
\hline 55 & $\mathrm{~S}$ & No \\
\hline 56 & $\mathrm{~L}$ & No (.) How about you? ((step to \\
\hline & & the right direction and approach \\
\hline & & another student)) \\
\hline
\end{tabular}

Miss Dolly just starts her lecture and introduces the topic, character and characterization. In lines 52-53, she wants to check the students' understanding of the materials at hand by asking a question about character. While asking the question, she also approaches the student (line 55). Getting no response from the first student, she poses the same question (line 56). She changes direction, moving closer to another student (lines 57-58).

Based on the results, the lecturers employ question-planning and question-controlling strategies. They pose close-display and open-referential questions to both individual students and the entire class. In the particular research, close display questions are mostly started with the auxiliary 'do', linking verb 'is' and 'are', modal 'can'. Meanwhile, the most common types of open referential questions are started with wh-questions such as 'what', 'why', 'where', 'who', and 'how'. Not only that, the lecturers also raise their intonation to indicate they are asking a question.

DeWaelsche (2015) has argued that experienced lecturers pose a large number and variety types of questions. Besides obtaining answers, posing questions in various ways and manners increases opportunities for meaningful participation and encourages interactive learning. Besides, the nature of question is to initiate a response, and questioning is found to be effective in getting students to speak out and promote oral fluency. After getting questions, students may directly reply, ask for help, or ask for more time. This is able to facilitate involvement, which fosters learning (Johnson \& Picciuolo, 2020).

More specifically, according to Kiramba and Smith (2019), display questions are posed to check students' understanding of the materials at hand and to give opportunities for students to use the target language in the form of response. Meguid and Collins (2017) have added that the use of display questions encourage learners, especially less proficient students to get interested. Meanwhile, referential questions are posed to get longer responses; therefore, they are more suitable for proficient learners. Follow-up questions are to invite for further discussion and extent student's contribution. However, in his study, Rido (2019) finds that an increase in the use of referential questions does not necessarily result in longer and better learner responses, which do not happen in this current research. The results of the research, to some extent, are in line with Rido (2017, 2019), Shi (2013), and Wangru (2016).

The results also reveal that the lecturers manifest the questions in some ways. First, the lecturers rephrase the question then nominate the students. Phrasing question first helps the students to have more time to think about the answer before giving their response. Meanwhile, nominating students helps the lecturers manage the distribution of questions and gives all students equal opportunities to be involved in the learning activity. These results, somehow, are contrasted with Tan (2007), who has revealed that most lecturers nominate active and good students only in order to lead the successive questions and make them a good example to motivate other students. Second, the lecturers ask the question to the entire class. This strategy is used in order to ensure students follow the lecture, get feedback as an indicator to repeat, or continue the lecture. According to Rido (2017), this strategy is able to encourage shy and passive students to participate because there is support from the friends through choir response. Third, the lecturer encourages the students to initiate questions, and forth, the lecturers move closer to the students while asking the question. Rido (2019) believes that besides obtaining answers, posing questions in these manners is able to increase opportunities for meaningful participation and encourage interactive learning. Besides, as the nature of question is to initiate a response, questioning is found to be effective in getting students to speak out and promote oral fluency. After getting questions, students may directly reply, ask for help, or ask for more time. This is able to facilitate involvement, which fosters learning (Milawati \& Suryati, 2019).

\section{CONCLUSIONS}

To conclude, the lecturers pose variety types of questions in their university English literature lectures, which are manifested in various ways. Principally, the questions are used as the tools to help the lecturers lead the students to think critically, increase their engagement during the lectures, and help the lectures to be more interactive. The findings offer implications and suggestions for pedagogical considerations within English literature lectures in the Indonesian university setting. The use of questioning strategies in the lectures makes the lecturers control the lessons, guides the students towards a particular response, and promotes interactions. In other words, the use of appropriate questioning strategies opens up space for the students to express their thoughts, which facilitates learning. Lecturers should plan their questions before asking to ensure that questions match the pedagogical goals. They should also ask questions, which requires students to engage in various kinds of verbal responses, which demonstrate a higher level of engagement.

The research findings are expected to fill the void 
in current English literature lecture pedagogy, mainly in the Indonesian context. Despite the increasing numbers of studies on questioning strategies in university lectures, there are still gaps; therefore, future research is necessary. First, it will be more interesting to involve various lecturers from different universities in future studies to get a broader and better picture of questioning strategies in university setting. Second, it will be richer to combine qualitative and quantitative methods in future studies. The use of questionnaires, for instance, strengthens the validity of the research findings.

\section{ACKNOWLEDGEMENTS}

The researchers are grateful to Universitas Teknokrat Indonesia for granting the research fund.

\section{REFERENCES}

Afrianto, \& Gulö, I. (2019). Revisiting English competence at hotel. Teknosastik: Jurnal Bahasa Dan Sastra, 17(1), 35-39. https://dx.doi.org/10.33365/ ts.v17i1.248.

Almohizea, N. I. (2018). An investigation of oral interaction in English as a foreign language classroom. International Journal of Language and Linguistics, 6(3), 51-60. https://doi.org/10.11648/j. ij11.20180603.11.

Blikstad-Balas, M. (2017). Key challenges of using video when investigating social practices in education: contextualization, magnification, and representation. International Journal of Research and Method in Education, 40(5), 511-523. https:// doi.org/10.1080/1743727X.2016.1181162.

Cahyono, S. P., \& Pribady, I. Y. (2020). Scaffolding in narrative learning: Appraisal analysis in teachers' talk. Teknosastik, 18(1), 59-71. https://doi. org/10.33365/ts.v18i1.553.

Creswell, J. W., \& Cresswell, J. D. (2018). Research design: Qualitative, quantitative, and mixed methods approaches ( $4^{\text {th }}$ Ed.). California: SAGE Publications, Inc.

DeWaelsche, S. A. (2015). Critical thinking, questioning and student engagement in Korean university English courses. Linguistics and Education, 32, 131147. https://doi.org/10.1016/j.linged.2015.10.003.

Fard, S. F. (2016). A short introduction to literary criticism. International Journal of Humanities and Cultural Studies, 3, 328-337.

Hauser, E. (2006). Conversation analysis: Studies from the first generation. Journal of Pragmatics, 38(9), 15321535. https://doi.org/10.1016/j.pragma.2006.03.002.

Jefferson, G. (2004). Glossary of transcript with an introduction. In G.H. Lerner (Ed.), Conversation Analysis: Studies from the First Generation (pp. 1331). Amsterdam: John Benjamin.

Johnson, J. H., \& Picciuolo, M. (2020). Interaction in spoken academic discourse in an EMI context: The use of questions. International Conference on Higher
Education Advances. Valencia, Spain. pp. 211-219. https://doi.org/10.4995/HEAd20.2020.11018.

Kiramba, L. K., \& Smith, P. H. (2019). "Her sentence is correct, isn't it?": Regulative discourse in English medium classrooms. Teaching and Teacher Education, 85, 105-114. https://doi.org/10.1016/j. tate.2019.06.011.

Leavy, P. (2017). Research design: Quantitative, qualitative, mixed method, arts-based, and community-based participatory research approaches. New York: Guilford Publications.

Liu, Y. (2019). Using reflections and questioning to engage and challenge online graduate learners in education. Research and Practice in Technology Enhanced Learning, 14(1), 1-10. https://doi.org/10.1186/ s41039-019-0098-z.

Mackey, A. (1999). Input, interaction, and second language development: An empirical study of question formation in ESL. Studies in Second Language Acquisition, 21, 557-587. https://doi.org/10.1016/ S1060-3743(99)80112-X.

Mahmud, M. (2017). Communicative styles of English students at the State University of Makassar. GEMA Online Journal of Language Studies, 17(1), 223-238. https://doi.org/10.17576/gema-2017-1701-13.

Meguid, E. A., \& Collins, M. (2017). Students' perceptions of lecturing approaches: Traditional versus interactive teaching. Advances in Medical Education and Practice, 8, 229-241. https://doi.org/10.2147/ amep.s131851.

Merriam, S. B., \& Tisdell, E. J. (2016). Qualitative research: A guide to design and implementation. California: Jossey-Bass.

Milawati, M., \& Suryati, N. (2019). EFL teacher's oral questioning: Are her questions and strategies effective? Dinamika Ilmu, 19(1), 37-55. https://doi. org/10.21093/di.v19i1.1545.

NACE. (2020). Job outlook 2020. Retrieved from www. naceweb.org \%7C.

Rana, A. M. K., Bashir, I., \& Abbas, F. (2020). English for future employment: The perception of Pakistani academia. Hamdard Islamicus, 43(2), 886-896.

Ranta, R., \& Harmawati, D. (2017). Analyzing teacher's instructional and nonverbal communication in EFL classroom. Lingual: Journal of Language and Culture, 4(2), 1-14. https://doi.org/10.24843/ ljlc.2017.v04.i02.p05.

Reid, D. A., Simmt, E., Savard, A., Suurtamm, C., Manuel, D., Lin, T. W. J., Quigley, B., \& Knipping, C. (2015). Observing observers: Using video to prompt and record reflections on teachers' pedagogies in four regions of Canada. Research in Comparative and International Education, 10(3), 367-382. https://doi. org/10.1177/1745499915580425.

Rido, A. (2017). What do you see here from this picture? Questioning strategies of master teachers in Indonesian vocational English classrooms. TEFLIN Journal, 28(2), 193-211. https://doi.org/10.15639/ teflinjournal.v28i2/193-211.

Rido, A. (2019). What is Newston's law of inertia? The use of questions in science lectures. LITERA, 18(2), 312- 
325. https://doi.org/10.21831/ltr.v18i2.21948.

Rido, A. (2020a). English for university graduate employability: Students and employers' voices. Advances in Social Science, Education and Humanities Research, 430, 6-10. https://doi. org/10.2991/assehr.k.200406.002.

Rido, A. (2020b). Why they act the way they do? Pedagogical practices of experienced vocational English language teachers in Indonesia. International Journal of Language Education, 4(2), 24-37. https:// doi.org/10.26858/ijole.v4i2.9935.

Rido, A., Ibrahim, N., Nambiar, R. M. K. (2015). Interaction strategies of master teachers in Indonesian vocational classroom: A case study. 3L: The Southeast Asian Journal of English Language Studies, 21(3), 85-98.

Rido, A., Kuswoyo, H., Ayu, R. (2020). Interaction management strategies in English Literature lectures in Indonesian university setting. Indonesian Journal of EFL and Linguistics, 5(2), 315-337. http://dx.doi. org/10.21462/ijefl.v5i2.286.

Rido, A., Sari, F. M., Suri, R. A. M., \& Duantoro, H. (2015). Discourse structure of lecture in L2 in the Indonesian tertiary context. Proceedings of ISELT FBS Universitas Negeri Padang, 5, 11-20.

Saleh, S. E. (2019). Critical thinking as a 21 st century skill: Conceptions, implementation, and challenges in the EFL classroom. European Journal of Foreign Language Teaching, 4(1), 1-16. https://doi. org/10.5281/zenodo.2542838.

Sari, F. M. (2019). Patterns of teaching-learning interaction in the EFL classroom. Teknosastik, 16(2), 41-48. https://doi.org/10.33365/ts.v16i2.139.

Shcheglova I. A. (2019). Can student engagement in extracurricular activities facilitate the development of their soft skills? Monitoring of Public Opinion: Economic and Social Changes, 6, 111-121. https:// doi.org/10.14515/monitoring.2019.6.07.

Shi, D. (2013). Teacher-student interaction in novel and poetry classrooms in the Hong Kong tertiary setting. Theory and Practice in Language Studies, 3(11), 1975-1982. https://doi.org/10.4304/tpls.3.11.19751982.

Simpson, R., Lee, D., \& Leicher, S. (2002). MICASE Manual. In MI: English Language Institute. Michigan: The University of Michigan.

Tan, Z. (2007). Questioning in Chinese university EL classrooms: Whatlies beyondit? RELCJournal,38(1), 87-103. https://doi.org/10.1177/0033688206076161.

Wangru, C. (2016). The research on strategies of college English teachers classroom questioning. International Education Studies, 9(8), 144-158. https://doi.org/10.5539/ies.v9n8p144.

Yang, H. (2017). A research on the effective questioning strategies in class. Science Journal of Education, 5(4), 158-163. https://doi.org/10.11648/j. sjedu.20170504.16.

Zhang, Z., Zhang, B., Shi, C., Qi, B., Zhou, J., Zhang, R., Li, J., Hu, Y., Sun, N., \& Meng, J. (2018). Casebased teaching approach to explore the impact of effective questioning on the teaching of "toxicology". Proceedings - $9^{\text {th }}$ International Conference on Information Technology in Medicine and Education, ITME 2018, 6, 411-414. https://doi.org/10.1109/ ITME.2018.00098.

Ziyaeemehr, A. (2016). Use of questioning techniques and the cognitive thinking process involved in studentlecturer interactions. International Journal of Humanities and Cultural Studies, 3(1), 1427-1442. 